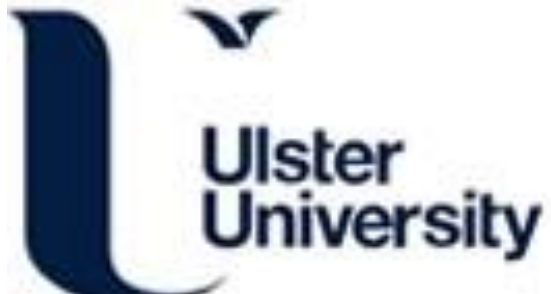

\section{The Scaffolding Activities of International Returnee Executives: A Learning Based Perspective of Global Boundary Spanning}

Roberts, M. J. D., \& Beamish, P. (2017). The Scaffolding Activities of International Returnee Executives: A Learning Based Perspective of Global Boundary Spanning. Journal of Management Studies, 54(4), 511-539. https://doi.org/10.1111/joms.12266

Link to publication record in Ulster University Research Portal

\section{Published in:}

Journal of Management Studies

Publication Status:

Published (in print/issue): 09/05/2017

DOI:

10.1111/joms.12266

\section{Document Version}

Author Accepted version

\section{General rights}

Copyright for the publications made accessible via Ulster University's Research Portal is retained by the author(s) and / or other copyright owners and it is a condition of accessing these publications that users recognise and abide by the legal requirements associated with these rights.

\section{Take down policy}

The Research Portal is Ulster University's institutional repository that provides access to Ulster's research outputs. Every effort has been made to ensure that content in the Research Portal does not infringe any person's rights, or applicable UK laws. If you discover content in the Research Portal that you believe breaches copyright or violates any law, please contact pure-support@ulster.ac.uk. 
The Scaffolding Activities of International Returnee Executives: A Learning Based Perspective of Global Boundary Spanning

\author{
Michael J.D. Roberts \\ Associate Professor \\ School of Business \\ MacEwan University \\ Edmonton, Alberta T5J 2P2 \\ Canada \\ Tel: 780-497-4236 \\ Email: robertsm35@,macewan.ca
}

\author{
Paul W. Beamish \\ Professor \\ Ivey Business School \\ Western University \\ 1255 Western Road \\ London, ON N6G 0N1 \\ Canada \\ Tel: 519-661-3237 \\ E-mail: pbeamish@ivey.ca
}




\begin{abstract}
This study contributes to the literature on global boundary spanning by taking a learning perspective that positions the boundary spanner as an active change agent. Grounded in a practice-based theory of knowledge, it considers boundary spanning as the negotiation of knowledge and relationships across fields of practice. We argue that global boundary spanning is a long-term commitment to help internal members become aware of foreign knowledge practices, see these practices as valuable, and adopt them internally. We frame the activities of the boundary spanner within a scaffolding framework that theorizes boundary spanning as a combination of ability, persistent willingness, and opportunity. Here scaffolding refers to the cognitive, relational, and material supports enacted by boundary spanners that facilitate organization members' engagement in practices that allow for the awareness, capacity building, and commitment to adoption of foreign practices. We draw on interviews from international returnee managers employed in large Korean financial firms.
\end{abstract}

\title{
KEYWORDS
}

Global Boundary Spanning; International Returnees, Scaffolding, Knowledge Theory 
This study demonstrates the importance of identifying the day-to-day work of boundary spanners in large organizations. Scholarly understanding of the phenomena is limited in that it downplays the everyday activities of boundary spanners. We deploy an iterative qualitative research approach by going back and forth between fieldwork and theory. The result is a model that links boundary spanning with a learning perspective based in educational theory (Lecusay, et al., 2008). In this model, the goal of global boundary spanning is to help organization members progressively learn from foreign knowledge practices and engage in meaningful ways with foreign stakeholders. We combined this with a view that boundary spanners are direct agents who work to help members negotiate collective knowledge across fields of practice (Levina and Vaast, 2006).

Conceptualizing knowledge as bounded within fields of practice emphasizes the everyday collective activities of a group that forms over time and within a social-historical context (Bourdieu, 1977, Levina and Vaast, 2006). Knowledge as practice is the understanding that the everyday practices enacted by people embedded in a context is what constitutes their knowledge (Orlikowski, 2002), and thus knowledge and practice are inseparable (Levina and Vaast, 2006). By taking a learning perspective, we complement papers in the boundary spanning literature that examine individual characteristics that predict boundary spanning behaviours. Boundary spanning facilitates the sharing of knowledge practices and the development of collaborative relationships across social context (Carlile, 2002, Kane and Levina, 2017, Mudambi and Swift, 2009, Schotter and Beamish, 2011). For example, Mudambi and Swift (2009) argue that boundary spanners are managers who can identify with the logics of individuals in both of the units that the manager is linking. They argue that skilled R\&D managers can act as boundary spanners by balancing the expectations, practices, and concerns of managers and scientists in R\&D intensive firms (Mudambi and Swift, 2009). This can be accomplished by developing 
resources that can be used to bridge gaps between members in different fields of practice (Levina and Vaast, 2005). More recently, Kane and Levina (2017) look at the importance of social identity (host or home country) as a predictor of a manager's inclination to engage in the practices of boundary spanning.

Our research question asks 'how' boundary spanners work with people in their organizations to build the capacity for integrating foreign knowledge practices. Boundary spanners are unique individuals in an organization who relate the internal organization to the external environment (Zhao and Anand, 2013). To address our research question, we develop a framework we call scaffolding. This framework was adapted from a social cultural learning perspective in educational theory (Lecusay, et al., 2008, Vygotsky, 1978). Scaffolding is a metaphor that views the introduction and absorption of knowledge across a field of practice as requiring temporary supports, much in the same way as the construction of a complex structure requires the use of scaffolding to support each subsequent phase of a building project. This scaffolding approach positions the boundary spanner as an active agent who provides support for organizational members while knowledge practices and relationships are transferred to and transformed within an organization from an external field of practice.

We define scaffolding in the context of global boundary spanning as the supports enacted by boundary spanners that facilitate organizational members' engagement in practices that allow for the awareness, capacity building, and commitment to the adoption of foreign practices. A scaffolding framework demonstrates that the adoption of foreign knowledge practices involves supports that are cognizant of the differences in fields of practice (Lecusay, et al., 2008) between the foreign practices and the organizational practices.

Scaffolds are important because without them there is a risk that members in the organization will not be able to recognize and value the boundary spanner's social or cognitive 
ties to external knowledge practice. This increases the possibility of either the external knowledge practice being resisted by individuals within the organization (Coleman, 1988) or, if initially accepted, more prone to failure during integration due to a lack of understanding of the knowledge practice (Rivkin, 2000).

This study followed an inductive approach where the scaffolding framework of boundary spanning emerged over several years in which the data were collected, analyzed, and then understood within the boundary spanning and education literatures. In order to contextualize the findings, we first present the relevant background literature. We have chosen this approach to facilitate reader clarity (Pratt, 2008, Schotter and Beamish, 2011). While we include a final model, the framework presented here was developed iteratively over the course of the study.

We begin with a literature review where we discuss and link a practice-based view of knowledge (Bourdieu, 1977) with educational theory (Vygotsky, 1978). Here we present the scaffolding model of boundary spanning which we later elaborate in the findings section. This is followed by an explanation of our research method. Based on insights gained from interviews with 45 returnee managers in South Korea that were collected over a two-year period, we develop the constructs of the scaffolding model. From these 45 participants, we further developed the model by focusing on four exemplary cases of senior managers who engaged in boundary spanning over their tenure with their domestic firm. They demonstrate the process model of scaffolding. The paper then moves to the discussion and conclusion.

\section{A Practice-based Approach}

Our conceptualization of knowledge is grounded in Bourdieu's (1977) practice-based theory of knowledge (Carlile, 2002, Kane and Levina, 2017, Levina and Vaast, 2005, Orlikowski, 2002). A practice view sees knowledge as an ongoing socially driven accomplishment 
(Orlikowski, 2002) that takes place by actors who are continuously learning by doing while using the tools that are available to them to accomplish their goals (Levina and Vaast, 2006). In this conceptualization, global boundary spanning is an active practice by managers, who seek to help their organization's members recognize and value external knowledge (Cohen and Levinthal, 1990, Mudambi and Swift, 2011) - specifically international knowledge and relationships.

Managing knowledge at a boundary is an iterative process (Carlile, 2004) that requires the development of new cognitive schema and alternative agreements and the need to overcome emotional attachment to previously successful practices (Carlile, 2002, Hsiao, et al., 2012). Boundary spanning takes time and is often only recognized after outcomes have been realised (Schotter, et al., 2017). Barner-Rasmussen, et al. (2014) argue that while boundary spanning involves linking external and internal groups, it is more profoundly about intervening in the process in such a way to mediate conflict, build competence, and negotiate meaning across boundaries. By engaging in the process of boundary spanning, selective managers produce new kinds of practices that serve to link individuals across boundaries (Levina and Vaast, 2005). As an iterative process, it is a continuous cycle of negotiating and reconciling differing interests (Birkinshaw, et al., 2017, Levina and Vaast, 2005).

However, managing knowledge practices across boundaries is often very complex, limiting the effectiveness of the actual knowledge transfer activity of a single boundary spanner (Szulanski, 1996). Zhao and Anand (2013) developed the concept of a collective bridge. A collective bridge exists when multiple members of the unit are linked to practices and people outside of their field of practice. Based on this multi-stakeholder perspective, Zhao and Anand (2013) present a contingency model which argues that many individuals are often required to act across boundaries in order to have successful transfer of knowledge practices. This contingency model, which theorizes the effectiveness of single boundary spanners versus a collective bridge, 
looks at 'who' must be involved for the effective transfer of knowledge practices. Often the individual boundary spanner is responsible for managing the flow of information but not the actual transfer of knowledge (Carlile, 2004).

Adopting new practices takes time and consistent effort from managers. The scaffolding model examines the question of 'how' managers facilitate the adoption of new practices by their organizational members. This adds to the literature that examines how boundary spanners go about helping individual members become ready to integrate new practice (Barner-Rasmussen, et al., 2014, Levina and Vaast, 2005, Mudambi and Swift, 2009, Zhao and Anand, 2013).

The argument that boundary spanning takes place over time and requires work on readiness is supported by change leadership models (Fry and Killing, 1989, Kotter and Cohen, 2012). When a leader wishes to introduce a new practice into an organization that requires members to substantially alter their knowledge practices, there is an imperative that the envisioned change be introduced in a way that is sensitive to the learning needs of the organizational members (Hendry, 1996). Kotter and Cohen (2012) argue that the single biggest mistake that change agents make is that they rush the sequential steps needed to accomplish the adoption of new practices.

Members of an organization require substantial time and resources to accept and integrate new practices that are unknown or in conflict with strongly held beliefs and practices (Orr and Scott, 2008). We add to theory on boundary spanning by developing a framework that places the global boundary spanner as a central agent in managing the introduction and integration of foreign knowledge practices into the organization. Boundary spanning thus involves more than the relationships and knowledge needed to link internal and external agents; it requires a persistent commitment to the processes and to the people who will be involved in the knowledge practices that result from the boundary spanning (Levina and Vaast, 2005). 


\section{A Learning Perspective of Boundary Spanning}

In light of the emphasis that has been placed on practices as recurrent and embedded (Orlikowski, 2002) and boundary spanners as those who work to integrate those practices (Levina and Vaast, 2005), scaffolding provides a way to frame these activities. Previous research on international knowledge transfer demonstrates that knowledge practices cannot be seen as a given commodity that can be packaged, rather it must be recreated in social practice (Tsoukas, 2009) and is thus inseparable from actors (Björkman, et al., 2004). It is for this reason that BarnerRasmussen, et al. (2014) consider bicultural and language skills as essential dimensions of the facilitating role that boundary spanners play in multinational enterprises.

Borrowing from educational theory, the work of boundary spanning involves creating scaffolding around external knowledge (Kokkonen, 2014), so that people who are unfamiliar with the context in which it was originally created can understand the new knowledge, develop the capacity to use it, and commit to adopting it (Lecusay, et al., 2008). A learning perspective fits with a practice view of knowledge in that it sees knowledge as emergent, embodied, and embedded (Orlikowski, 2006). Boundary spanning arises from the emergent demands of everyday activities as a response to ongoing barriers that develop between inter-boundary actors (Orlikowski, 2002). Boundary spanning activities are embodied in the knowledge and experience of the boundary spanner, the workgroup members, external actors, and material objects (e.g., information systems, operational or strategic plans). They are embedded in the socio-historical contexts of the national and organizational cultures (Orlikowski, 2002).

\section{Scaffolding}

Within the field of education, Vygotski's Zone of Proximal Development (Cole, 1985, Vygotsky, 1978) is a theoretical framework that combines these complex relationships within the 
context of learning. A Zone of Proximal Development is a 'cognitive space' in which new knowledge is not so distant from the receiver that it is completely beyond the receiver's ability to recognize and value, but at the same time unfamiliar enough to provide a challenge to introduce new concepts. It is the distance between actual development under independent problem solving and a potential level of development in collaboration with a mentor or more capable peer (Vygotsky, 1978, Warford, 2011). The role of the facilitator is to frame the knowledge close enough to the receivers so that they can grasp the knowledge and integrate it into existing experiences, while providing rich material to maximize development (Aljaafreh and Lantolf, 1994, Kinginger, 2002).

Within the Zone of Proximal Development, the metaphor of scaffolding has been developed to explain the work of the actors involved in the transfer of knowledge practices. Scaffolding provides the critical tools to achieve a progressive set of goals (Wass, et al., 2011). In the construction of a tall building, scaffolding is used to create a frame to help workers progressively build. This analogy is extended to tools available to help individuals reach their next immediate goal. The concept is useful because it reinforces the notion that the receiving and integrating of new knowledge practices is a complex and incremental process (Koole and Elbers, 2014).

Scaffolds are not a permanent part of a structure and are thus not ends to themselves, but rather extend, link, reconfigure, and transform the people, knowledge, and resources needed to transfer knowledge (Orlikowski, 2006). They are processes put in place to help shape and guide the activities of knowledge transfer (Alexander, et al., 2015). Scaffolds extend the agency of actors across geographic locations by providing the social and physical resources needed to access external networks (Best, 2011). Scaffolding creates temporary links so that information flows can occur even when the internal network does not have these capabilities (Orlikowski, 
2006). It provides a means of reconfiguring relationships and knowledge so they can be transferred within the capabilities of the internal network (Yearwood and Stranieri, 2010). Finally, scaffolding allows for the transformation of knowledge and relationships into organizational capabilities (Orlikowski, 2006). In this way, scaffolds are what allow knowledge practices that are novel and absent from current practices to be introduced and embedded into an organization.

Boundary spanners are managers that satisfy the needed conditions for facilitating scaffolding. Scaffoldings are the activities that boundary spanners enact in order for organizational members to engage in relationships and knowledge development across fields of practice. These scaffolds must be within the Zone of Proximal Development of organizational members in order to be effective. The findings section of this paper develops a richer understanding of (a) the conditions that enable managers to become boundary spanners who facilitate scaffolding; and (b) the scaffolding activities of these boundary spanners as they are enacted within the Zone of Proximal Development of organizational members.

Boundary spanners may create scaffolding for individuals in more than one field of practice, such as in the context of Mudambi and Swift (2009) where the boundary spanner is working with managers and engineers. However, scaffolding may be targeted towards individuals in one field of practice. In such cases, the boundary spanner is working with internal members to prepare them to integrate practices from an external field.

\section{Data and Methodology}

The theoretical contribution of this paper emerged from a specific phenomenological context (Burgelman, 2011). This context was international returnee managers in large Korean firms which previously had limited exposure to foreign markets. International returnees are 
individuals who through self (or family) selection have gone abroad to study, live, and/or work, then return to their home country (Dai and Liu, 2009, Lee and Roberts, 2015). As such, returnees have gained their foreign knowledge and experience outside of the firm in which they are currently employed. Previous studies have already demonstrated that international returnees can provide valuable linkages to foreign practices (Rhee and Lee, 2008). Returnees offer a potential for boundary spanning because they have been embedded over time in at least two national environments (Lee and Roberts, 2015, Pruthi, 2014). The practices that they have experienced in the foreign environments in which they lived, studied and worked, and the domestic networks that they have left and to which they have returned, potentially allow them to "play an important role in the establishment of linkages between home and former host systems" (Jonkers and CruzCastro, 2013: 1368).

We began the study, however, with strong anecdotal evidence that senior managers felt international returnees were only sometimes effective at contributing to the understanding and integration of foreign practices within the organization. This was based on pilot interviews with two HR managers in large Korean firms. Thus, we believed that the boundary spanning role of international returnees in large firms was a phenomenon best studied in context (Doz, 2011).

Our research methods are qualitative and inductive. Consistent with the constructivist theory approach, we began with the researchers' understanding of the phenomenon, and iteratively included academic literature and insights from the data analysis (Charmaz, 2014). We used this approach because our research question asked 'how' (Eisenhardt and Graebner, 2007) international returnee managers go about the work of helping their organizations integrate foreign knowledge practices. The role of returnees in large organizations, as opposed to returnee entrepreneurs (Filatotchev, et al., 2009), has been an under-studied phenomenon. Thus for this study and consistent with Miles and Huberman (1994), we emphasize the development of new 
insight as opposed to initially obtaining generalizability.

An interview strategy (Daniels and Cannice, 2004, Denzin and Lincoln, 2005, Erlandson, et al., 1993) was employed to obtain the personal stories of returnees over their career. Because the returnee experience of boundary spanning unfolds over many years, great care was taken to ensure that they focused on concrete examples from their experiences (Huber and Power, 1985, Yagi and Kleinberg, 2011).

\section{Research Setting and Data Collection}

The study was motivated by the authors` interest in the role of returnee managers in large organizations. The first author had access to managers in organizations that were actively recruiting returnees. We then conducted a pilot interviews with senior returnee managers, which helped to guide research question development. Informed by the pilot study, we returned to Korea two more times to interview returnee managers in large firms. Data analysis, literature reviews, and theory development occurred iteratively over the entire course of the study (Glaser and Strauss, 1967). In accordance with the chosen qualitative method, interview data was compared with existing literature until we were satisfied we had achieved theoretical saturation (Glaser and Strauss, 1967).

Our data collection primarily consisted of interviews with 45 managers over a 2-year period. All notes were in the form of a diary with a date and time entry. All in-depth interviews were transcribed and entered into a case database as documents. The interviews were then coded using the software package NVivo. Table 1 summarizes the number of participants interviewed during each stage. The study began with 14 interviews with senior managers at large Korea-based firms who were returnees. We began with a question suited to naturalistic inquiry (Erlandson, et al., 1993): 'What does it mean to be an international returnee in the context of a large Korea- 
based organization?' Two themes clearly emerged from the initial 14 interviews. First, returnees are hired into large Korean firms because the firms believe that they can contribute the knowledge of practices they learned in foreign markets. Second, the transfer of these practices across fields of practice is far from straightforward.

Insert Table 1 about here

The interviews from the pilot phase helped shape the nature of our next research question. Several interviewees used terms such as coaching, negotiating, and educating to describe their role in connecting locally hired managers to foreign practices and people. This led us the question of "how do returnees go about the work of boundary spanning?" This micro-level emphasis is a context-based phenomenon, and as such the activities of the actors are not easily isolated from the people and organizational settings in which they occur (Lupton and Beamish, 2014).

The participants were introduced to the authors by a colleague from the returnee's firm or from a person who had a professional relationship with the returnee. We were able to compile background information from the person introducing the returnees before interviewing them. This often provided us informal insight into each returnee's attitudes and performance within the firm. Notes from these introductions were included in the case reports (Yin, 2009). These notes helped provide triangulation (see: Gibbert, et al., 2008) during the data analysis by allowing us to understand the returnee's comments in the context of an informal assessment from their colleague. In order to create as much theoretical replication as possible, returnees were asked to suggest colleagues in their firm who might also be willing to participate in the study. This allowed us to compare and contrast the experiences of returnees within the same organization. When an interviewee suggested another colleague as a potential participant, they were asked to 
provide insight into the colleague's experience within the firm. These comments were also added to the case study notes.

In order to facilitate the interviews, a semi-structured interview guide was created. We used an open-ended interview approach (Yin, 2009). The first set of questions asks about the knowledge that returnees believe they bring to the organization; the second set asks how they attempt to integrate that foreign knowledge into their workgroups. The list of discussion questions was sent by email. In some cases, a series of email exchanges occurred to help clarify the study and the questions. Thus, the returnees were prepared for their interview in advance. Most interviews occurred in the returnees' offices and lasted 45-90 minutes. The email and phone exchanges improved the efficiency of arranging meetings, and in many cases were important for gaining consent.

Following the development of the semi-structured interview, 28 returnees were interviewed - with 5 of the returnees from the exploratory phase being re-interviewed. After coding began on the interviews, and themes started to emerge, the first author returned to Korea to follow up with 6 returnees from the most recent interviews and to interview 8 more returnees.

Notes were taken at three stages: (a) based on the introduction that was provided by the contact person, (b) immediately following the interviews, and (c) during interview analysis to describe any insights or discoveries made.

Table 2 provides a summary of the descriptive statistics for the 45 returnees who participated in the study. Table 3 presents a summary of the 16 firms that represented the sample. We interviewed 1 to 8 returnees in any given firm.

Insert Table 2 and 3 about here

The theoretical insights for our scaffolding model were informed by all of our interviews 
in an iterative process. We began by carefully reviewing the transcripts to tag the participants' examples, stories, and facts with a code that reflected what they were expressing. We did this through constant comparison (Strauss and Corbin, 1990). Codes were developed and refined as we repeatedly read through the transcripts. From early on, two distinct bundles of codes emerged from this process. The first set of codes focused on the conditions which must be in place in order for a boundary spanner to engage in the integration of foreign practices with colleagues. The second set of codes focused on the types of scaffolding activities that they enacted.

The second step was to review the codes to look for similarities and patterns between codes (Basu, et al., 2015, Locke, 2001, Stigliani and Ravasi, 2012). Informed by the data collection process, data analysis, and the literature on change management (Fry and Killing, 1989, Kotter and Cohen, 2012), boundary spanning (Barner-Rasmussen, et al., 2014, Levina and Vaast, 2006, Mudambi and Swift, 2011), and the educational theory of scaffolding (Lecusay, et al., 2008, Vygotsky, 1978), three categories emerged which corresponded to the conditions for boundary spanner scaffolding. These were: (1) that returnees must have an ability to engage in scaffold building; (2) that they must demonstrate a willingness to persist over a long period of time in order to realize results; and (3) that they must be given or create opportunities to engage in scaffolding activities. We develop these three categories further in our Findings section.

In addition, three categories emerged related to the types of scaffolding activities that boundary spanners enact. These relate to cognitive or knowledge building scaffolding; relationship building scaffolding; and, the enactment of material scaffolding through physical or organizational supports. In the Findings section, we develop each further by connecting them to the interview data.

What emerged from the interviews was that most returnees exhibited some conditions for boundary spanning, and many engaged in some scaffolding activities. However, only a few 
returnees met all of the conditions for boundary spanning, and engaged in a wide variety of activities consistently over a long period of time. While some of the younger returnees we interviewed may eventually demonstrate substantial boundary spanning, their achievements were limited by their career stage.

Thus, after we developed the model, we focused on four senior managers who had been with their Korean firms for many years and who had substantial foreign knowledge and personal networks. These managers represent a subset of the interviews we conducted with 45 international returnees. At the time when these returnees joined their firms, these firms had little exposure to foreign markets. As such, these international returnees joined firms where conditions for effective boundary spanning did not exist. This has allowed us to study boundary spanning in a more nascent environment. Table 4 presents a summary of the four focal cases.

Insert Table 4 about here

The four focal cases were chosen because these returnees (a) had substantial foreign knowledge and experience, (b) had been with their organizations for many years, and (c) were now senior level managers who could reflect back on the integration of foreign knowledge into their firms. Thus, while our broader dataset greatly informed the development of the scaffolding model and answered questions pertaining to the type of returnee engaged in boundary spanning or the transfer of knowledge practices, this subset allowed us to develop theory on 'how' returnees engage in boundary spanning over an extended period of time.

Our constructs related to the conditions and activities were developed based on the analysis of all data. Even participants who did not demonstrate substantial scaffolding behavior contributed to our knowledge building. For example, a participant might stress that they had no opportunity in the firm for boundary spanning. Other participants felt that they had very little to 
offer their colleagues in terms of foreign knowledge practices. Yet others reported that they had given up in frustration. In this way all inputs from participants were important. In keeping with the understanding that global boundary spanners are rare (Schotter and Beamish, 2011), it was not surprising that we found a limited number of exemplars of the model.

From the first order constructs we developed second order constructs which were related to the conditions of the boundary spanner (ability, persistent willingness, and opportunity) or scaffolding activities of the boundary spanner (cognitive, relational, and material scaffolding). The first and second order constructs were re-arranged through numerous iterations until we were satisfied that our model best represented the data and no new theoretical construct would emerge from the data (Miles and Huberman, 1994). Finally, what emerged from the data was that the processes that the participants described were recursive. When each of the four cases was read in its entirety and in light of the above coding, they all told a story of the boundary spanning processes occurring incrementally over a long period of time.

\section{Findings}

Our data analysis uncovered two sets of constructs related to how boundary spanners go about the process of developing organizations capable of integrating foreign knowledge practices. First we found that boundary spanners are unique managers in that they satisfy three conditions which allow them to relate the internal organization to external context or knowledge. In turn we discuss each of these (ability, persistent willingness, and opportunity.) Second, we found that boundary spanner managers enact three types of scaffolding. In turn, we then discuss each of these (cognitive scaffolds, relational scaffolds, and material scaffolds.) Figure 1 shows the dimensions of each of the three conditions for boundary spanner scaffolding and provides representative quotes from the data for each one. 
Insert Figure 1 about here

Ability

Ability is a combination of foreign knowledge, social capital, and vision. Through their international experience, knowledge, and relationships, global boundary spanners build up social ties and shared cognitive frameworks with foreign actors (Granovetter, 1973). Employing managers with significant foreign experience can be a means of facilitating foreign knowledge transfer (Harzing, et al., 2016). This becomes knowledge and social capital (Tsai and Ghoshal, 1998) that can be used to help facilitate external knowledge recognition. Social capital represents the interpersonal relationships that a person has built and the resources embedded in those relationships (McFadyen and Cannella, 2004). Research has found that social capital can contribute to a firm's ability to develop innovative solutions (Landry, et al., 2002). Knowledge is the sum of experiences gained in foreign work and educational settings.

In our study, senior executive returnees often called upon their foreign networks and knowledge gained while overseas to help their colleagues bridge international boundaries. As an example of knowledge of foreign practice and use of social capital, IR1 explained how he drew upon social capital to begin the processes of introducing his colleagues to the opportunities that existed in foreign markets. He did this as a way of readying them for international expansion. When he entered the firm, his colleagues had no experience in foreign markets and almost no network outside of Korea. In order to introduce them to foreign knowledge practices and possible partners, he opened a series of seminars where he invited executives from foreign companies, who were part of his professional network, to give lectures to executives in his current firm. By linking colleagues to his foreign network, he was creating informational and relational links to the international environment. 
Another important dimension of ability is vision. Beyond the experience and knowledge of external knowledge practices, boundary spanning requires a long-term vision of how the organization could be enhanced by the adoption of a foreign knowledge practice. IR1 offered an example of vision. He understood where his firm needed to go over the next several years. His ability was not just his possession of social capital and knowledge of foreign practices, but an understanding of why such boundary spanning had long-term importance. He explained that he did this because if the firm wanted to eventually conduct substantial international business they had to have people in leadership positions who possessed a deep insight into the competitive environments of those markets. He knew that this had to include more managers than just members of his small team and himself. The seminars were merely a first step. According to IR1, “this doesn't happen by accident. It takes time to develop these guys.”

Vision is not trivial, as the final goal may often be years away and thus not achievable given the current practices of the organization. IR1 knew that introducing his network of foreign business colleagues would not, in and of itself, lead to his senior colleagues successfully engaging in foreign business or adopting foreign practices. It was one step toward a long-term change vision. Thus, ability has both an immediacy (ability to do something now) and a visioning component (ability to lead an organization toward a greater goal).

\section{Persistent Willingness}

The second condition for boundary spanning is willingness to persistently engage in boundary spanning activities. Willingness originates in a variety of ways, including extrinsic motivation or social pressures (Kane and Levina, 2017). However, we found that persistent willingness requires a long-term commitment that stems from intrinsic motivation (Mudambi and Swift, 2009). It involves a commitment to the initiation of new practices and the fostering of the social relationships needed to execute them. 
Connecting the internal organization to the external environment for the purpose of creating new knowledge practices is a disruptive process in that it involves changes in practices and routines (Orr and Scott, 2008). In fact, attempts to incorporate foreign practices into an organization almost invariably lead to conflict (Birkinshaw, et al., 2000, Schotter and Beamish, 2011). Thus, qualified individuals may choose to avoid the uncomfortable situations that are implicit in the work of boundary spanning (Levina and Vaast, 2005).

Björkman, et al. (2004) in their work on knowledge transfer provide two perspectives to explain willingness. From an agency perspective, they see external motivating mechanisms such as performance criteria and compensation structures as influencing managers' willingness to transfer knowledge across boundaries. In our study, returnee managers expressed a sense of obligation to their firms. They indicated that they were recruited to their firms at a premium salary and were, at least partially, evaluated on their ability to effectively seek out foreign knowledge practices and relationships. From a socialization perspective, social relationships within the firm can drive a willingness to transfer knowledge. The participants in the study mentioned the desire to gain social legitimacy within the organization as driving their willingness to act in boundary spanning roles (Schotter and Beamish, 2011).

To this we add that for global boundary spanners, willingness to engage in boundary spanning comes from a personal commitment to the organization regarding the benefits of pursuing international opportunities and practices over the long term. Our interviews revealed that boundary spanning involves individual initiation and the work of boundary spanning is best described by the causal ambiguity of an effectuation approach to management (see Sarasvathy, 2001). It involves repositioning existing social capital in dynamic ways (Pruthi, 2014) and developing knowledge practices in an environment of uncertainty. In addition, such knowledge practices are often embedded in highly structured national and organizational environments 
(Levina and Vaast, 2008). As such, it should be expected that substantial change to knowledge practices will be met with resistance (Schotter and Beamish, 2011). Thus, boundary spanners must have the intrinsic motivation to persist in the face of resistance from members embedded in current practices (Mudambi and Swift, 2009).

In the context of international returnee executives in Korea, IR2 illustrates the need for this sustained commitment. Despite early frustrations, IR2 stuck with his boundary spanning efforts despite an initial lack of recognition or reward. He provides an interesting example of this. Early in his career, he attempted a project that initially seemed straightforward. His goal was to develop an online insurance platform based on the model used in the American firm he had worked for, but lacking in the Korean insurance industry. After a half year of planning by his team, the project was shut down by colleagues and senior executives. In retrospect, IR2 came to understand that his colleagues were not actually opposed to a project having an online presence based on an American model. Rather it was that they lacked a sufficient understanding of the practices that were involved in carrying this out. They could not adopt a foreign knowledge practice they did not understand. Within a few years and with more careful attention to building the necessary knowledge base, the platform was adopted by the firm. Thus, boundary spanners must be willing to persist in spite of resistance that results from a lack of understanding of foreign knowledge practices. Part of willingness is the patience to enact scaffolding in order to integrate knowledge practice within the organization.

\section{Opportunity}

Opportunity is the third condition that makes boundary spanners unique. We observed that boundary spanning efforts of the returnee managers involved actively searching for opportunities for their firms to integrate foreign knowledge practices. Willingness and ability are necessary but not sufficient conditions for boundary spanning to occur. One must be afforded the 
opportunity to engage in boundary spanning practices. Opportunity is a function of organizational structures and receptiveness by internal members. In order to engage in boundary spanning, potential global boundary spanners need legitimacy within the internal organization to help members access foreign knowledge and put it into practice (Allen, et al., 1979). IR2 discovered that it was not enough to have a good proposal, one must gain the confidence of colleagues first. His initial failure to introduce the online platform was a learning experience. He realized that he was being overambitious without first working to create the buy-in necessary from managers throughout the organization. In retrospect, he believes his failure was not that the idea was unacceptable, since they did eventually implement it, but rather he felt his colleagues did not have a sufficient understanding of the practice.

Legitimacy can arise from either being a nominated boundary spanner or a boundary spanner-in-practice (Levina and Vaast, 2005). A nominated boundary spanner is a person who serves in a boundary spanning position by virtue of the formal role they have within the organization. A boundary spanner-in-practice is a person, irrespective of formal position, who engages in boundary spanning activities. Levina and Vaast (2005) demonstrate that nominated boundary spanners do not necessarily engage in boundary spanning activities. While such people may have opportunity, they do not necessarily have ability or willingness (Kane and Levina, 2017).

The international returnee executives whom we interviewed in Korean financial firms reported that these firms tended to be highly insular in foreign knowledge practices. Most were just beginning to open up to foreign market players as a response to the financial reforms that followed the 1997 financial crisis (Grewal and Tansuhaj, 2001, McKibbin and Martin, 1999). While there was a sense from the leadership in these firms that they could benefit from foreign knowledge practices and stronger ties with foreign partners, most firms had very limited 
organizational capabilities to realize these opportunities.

Not all international returnees could become global boundary spanners. Only some had the relevant education and work experience to have the ability to help their organizations recognize and value foreign practices and relationships. Others may not have had the willingness to engage in the conflict that is often associated with boundary spanning activities. However, one of the clearest challenges for returnee executives in large financial firms was a lack of opportunity for boundary spanning.

This lack of opportunity came from rigid knowledge practices that had been developed and maintained over decades in these organizations. Returnees reported entering firms where colleagues did not have the cognitive or semantic (Carlile, 2002) knowledge to engage in meaningful discussions about foreign practices. The firm had not established trustworthy relationships with foreign partners - an essential dimension of boundary spanning (Mudambi and Swift, 2009). The firm did not even have the organizational capabilities such as physical offices or even operational procedures for engaging in overseas business. Beyond that was the emotional attachment to practices and relationships that had worked well in earlier years (Carlile, 2002).

When IR1 first began the work of incorporating foreign practices into the firm, his most significant obstacle was reluctance on the part of other managers to adapt current practices. In the highly institutionalized environment of Korean financial institutions, real boundaries existed where "actors must be able to represent current and more novel forms of knowledge, learn about their consequences, and transform their domain specific knowledge accordingly" (Carlile, 2004: 559). These often represent an obstacle that seems initially to be insurmountable for fruitful boundary spanning. IR1 explained that for him the limit to introducing a new practice was how far out of "their comfort zone" he had to push his colleagues. Even when the practice was conceptually appealing, comfort levels had to be managed. He explained that "when I approach 
my colleagues with a fresh idea, they often buy it the first time. 'WOW! That's a great idea.' But when it comes time for implementation, they tend to still believe in what they know."

In this context, creating an environment where able and willing managers were given the legitimacy to practice boundary spanning took significant long-term commitment from these individual managers. They did this by enacting scaffolding to support their colleagues' integration of foreign knowledge practices. Figure 2 includes the dimensions of each of the types of scaffolding activities and provides quotes from participants that illustrate these dimensions.

Insert Figure 2 about here

\section{Cognitive Scaffolding}

Boundary spanners enact cognitive scaffolds that build an understanding of foreign practices. Three dimensions of cognitive scaffolding were reported: language and cultural scaffolds; conceptual scheme scaffolds; and mentoring scaffolds. The participants reported that adopting foreign practices was difficult because many of their colleagues did not have the shared foreign language, cultural, or fundamental understanding of the conceptual scheme needed to engage in a foreign practice. This was often reported as a training issue. Senior managers reported that they directed and financially supported colleagues in developing the necessary language and cultural skills needed to engage foreign partners. Language and cultural development was often seen as the first necessary scaffolding before other scaffolds could be enacted.

Beyond language development in the strict sense, managers stressed that they spent considerable time building a conceptual scheme with their colleagues. Building the actual language skills was a straightforward training problem that could be arranged through in house or private training. The participants explained that they could not propose new managerial or 
organizational practices because their colleagues did not have the shared conceptual scheme needed to grasp the practices. Some of the activities that they engaged in to build language and social schemas included giving lectures and workshops or working directly with other colleagues on a regular basis. This was often accomplished through mentoring. IR3 looked at scaffolding as a type of mentorship activity that required him to put significant time and energy into developing other colleagues. He reported spending much more time with the individual team members than would an average [domestic] executive. He believed that there was much that could be gained by working side by side to show how foreigners think.

\section{Relational Scaffolding}

Boundary spanners also enact relational scaffolding. Three dimensions of relational scaffolding were reported. The first was facilitating external benchmarking by bringing colleagues overseas. Benchmarking missions can be a valuable way for colleagues to meet foreign partners and learn about foreign knowledge practices. As a Senior VP from a large manufacturing firm pointed out, these benchmarking trips allow local managers to build relationships with foreign partners while learning new and best practices in the industry. The end goal of this type of scaffolding activity is allow colleagues to meet relevant partners and develop relationships that are independent of the boundary spanner. However, as with most scaffolding activities, the end goal is achieved over a long period of time. Thus, this is an incremental process. All four returnees reported that this took the form of leading external benchmarking missions, and actively managing relationships between internal colleagues and foreign partners.

Several returnees also reported that they facilitated relationship building by hosting foreign partners from their personal network to meet with executives in their firm. These introductions helped legitimize relationships. These introductions often happen in workshops, seminars, and meetings that were outside the regular work environment. 
An important relational scaffolding is direct involvement in relationship development for the purpose of negotiating substantial inter-firm level agreements such as joint ventures or acquisitions. Some of the more senior executives were involved in this type of advanced scaffolding activity. Several senior returnee managers pointed out that part of their role was to build the relationships needed to pursue successful alliances with foreign partners.

\section{Material Scaffolding}

Material scaffolds are "physical objects, spatial contexts, and technological artifacts" (Orlikowski, 2006). Material scaffolding make use of boundary objects (Carlile, 2002) in a way that allow them to be utilized within the Zone of Proximal Development of the organizational members. Common examples that the participants cited were providing written documents such as manuals and guides to help facilitate the understanding of foreign practices. Also, given that language barriers existed, returnee managers often had foreign documents translated so that they would be more accessible for colleagues with limited foreign language abilities.

A common material scaffolding approach was to create learning spaces for the development of foreign practices. Participants reported that developing and engaging in new foreign practice on the job increased likelihood of rejection. Thus, a common technique was to alter spatial conditions by relocating to a training facility. The example in Figure 2 of introducing new valuation techniques into a financial firm is a good example of this type of scaffolding. Here, the scaffolding activity took place over a period of time and outside of the regular office. From basic knowledge building to implementation, the activities were separated from the regular workspace. This approach was to make the entire process "a lesson, not a threat".

Providing proof of concept is also a material scaffold. Foreign practices can be quite difficult to comprehend because the stakeholder may lack a common frame of reference. Allowing decision makers to experience a practice before enacting it can increase acceptance. 
The example in Figure 2 of proving the concept by using evidence that goes beyond what would usually be required is an example of this activity.

\section{The Recursive Scaffolding Model of Boundary Spanning}

The context of this study allowed us to examine the starting point of a scaffolding framework and consider how the scaffolding model is enacted by boundary spanning managers.

\section{Conditions for Boundary Spanning}

The framework begins with the initial conditions for boundary spanning. This context commences with a potential boundary spanner who meets the conditions needed for boundary spanning and who is embedded in and/or introduced to a situation where organizational members do not have the capability to engage in an external field of practice. In our study, these were returnee executives in large Korean financial firms which were only beginning to open up to foreign markets. Opportunity may come from a mandate from the firm to act as boundary spanners or they may self-identify and seek out opportunities. Ability is derived from experience and an overarching vision of a substantial end goal that could be accomplished if rigid boundaries were to be overcome. This means that the potential boundary spanner has the ability, through both previous international knowledge and work experience. The boundary spanner must also have willingness to engage in boundary spanning activities. The final process model for the scaffolding framework of boundary spanning is presented in Figure 3. Conditions for boundary spanning are shown at the top of the model. We use the illustrative case of IR4 to explicate the model.

Insert Figure 3 about here

IR4 indicated that when he returned to Korea as a manager, he knew there was huge potential for his firm if they could capitalize on foreign investment both from and to the United 
States. As the Korean market was just opening, this had never before been possible. His ability resulted from the knowledge and relationships he developed overseas and the vision he brought with him from those experiences. However, it was clear that his colleagues and senior executives did not have the knowledge, relationships, or the administrative heritage to take advantage of what he could offer. IR4 argued that his first task was to find an opportunity to introduce these foreign practices given the limited capacity within the firm.

Thus, for IR4 willingness was necessarily long term focused. He knew from the start that he would need to have persistent willingness to achieve his long term vision of introducing substantially new foreign practices and partnerships into the firm.

IR4 understood that developing a substantial partnership with a foreign investor was a potentially lucrative opportunity for his firm. However, this was not a proposal that he could even begin to bring to his senior colleagues. In fact, while they were aware of the increasing importance of foreign investors in Korea, the organization members lacked even the basic knowledge, relationships, and organizational support to engage in such a venture.

\section{Early Scaffolding}

While boundary spanners certainly look to the end goal, they also focus on opportunities that can be accomplished now within the Zone of Proximal Development by the people and resources of the organization. By focusing on the current Zone of Proximal Development and building appropriate scaffolding, boundary spanners are more likely to have organization members extend them further. Thus, the boundary spanner looks for a goal that both pushes the organization toward an ultimate goal and is achievable given the current development of the people and resources. They provide scaffolding to achieve this goal.

IR4 knew that with the increased investment in foreign capital into Korea (primarily from the United States), the dealers could make better buying and selling decisions if they understood 
what was going on in the American market. However, they didn't know what they needed to know, nor how to go about developing these skills. Thus, he began with cognitive and material scaffolding that was within the Zone of Proximal Development of members of his firm.

I gathered the dealers together at 8:00 am each morning for 30 minutes. We would go through all the important events. Thus, before I met them I would read all the important financial newspapers, like the Wall Street Journal, and watch CNN. I sometimes explained the specific techniques or market structures or government institutions that form the U.S. market systems.

As a senior manager in a busy financial firm, teaching a Wall Street Journal class to junior colleagues seems a rather mundane task. However, it developed a cognitive understanding

of the foreign markets, which created some intelligence with the organization. Also, there was no one else in the firm who could do this or who saw it as valuable. Most importantly, it was a financial win. The firm made more money and senior managers took notice.

In Figure 3, this is shown as the first iteration of scaffolding provided by the boundary spanner to individuals within the firm. In this example, these were cognitive (scheme building) and material (providing learning spaces and physical materials). This led to some legitimacy which opened the door to future opportunity. This piece of scaffolding helped build the ground floor. Both the legitimacy which came from this, and the knowledge that came from the scaffolding work, increased the Zone of Proximal Development of organizational members for foreign knowledge practices.

\section{Scaffolding and Increasing Zone of Proximal Development}

In Figure 3, the arrows that lead from the members up to the scaffolding and up to the conditions for boundary spanning show that the Zone of Proximal Development increases with each iteration of scaffolding. Following this success with his junior colleagues, IR4 was invited to work with his senior colleagues to help them get ready for internationalization. He accompanied them on overseas benchmarking trips. He debriefed the senior colleagues after 
meetings with potential foreign partners so that they could understand the nuanced language of their American counterparts. This scaffolding in turn increased the organization members' Zone of Proximal Development.

The boundary spanner uses the results of the first scaffolding effort and erects another set of scaffolding to build the next floor. The boundary spanners are thus individuals who increase the size and scope of the scaffolding, such that over time it allows individuals to then achieve future goals.

\section{$\underline{\text { Scaffolding as Iterative and Responsive }}$}

Not all scaffolding looks the same. What is needed for some managers at a given time may be different than what other managers require. Over the long term, the same managers within the organization may require different scaffolding to achieve the next progressive goal. The important thing for the boundary spanner is to continue to provide the next layer of scaffolding to ensure that managers progress within their Zone of Proximal Development.

The boundary spanner is not only providing the required scaffolding, but is also scanning the environment to understand what is needed, for whom, and when. In this way, the conditions of boundary spanning (ability, persistent willingness, and opportunity) are affected by each iteration. The needs of organizational members cannot always be anticipated and are not the same for everyone. Also, organizations experience both learning and forgetting (Hendry, 1996). Thus, as managers enter and exit the firm or change roles within the firm, scaffolding may need to be redeployed. As resources are put in place, managers develop cognitive and relational skills, new scaffolding is erected, and the firm moves closer to its ultimate goals.

When a boundary spanner stays committed to building incremental scaffolding for a long enough period, several things happen. Organizational members develop the cognitive skills and relationships they need to accept and execute the vision. The external knowledge becomes 
transformed so that it is now internal and contextualized within the organization. The organization develops the broader set of solid resources needed to make the change successful. The early scaffolding becomes redundant and the boundary spanner enacts more sophisticated scaffolding. In addition, the boundary spanner develops not only the skills needed to provide sophisticated scaffolding but also the relational power required for the legitimacy. Thus, boundary spanner conditions improve.

\section{$\underline{\text { Scaffolding Involving Individuals in Multiple Fields of Practice }}$}

IR4 used his early successes in the firm to build a position as a legitimate boundary spanner in practice and then over time was given an opportunity for a more formal nominated boundary spanning position. After some years, the firm was better prepared for more complex interactions with foreign market players. By enacting increasingly sophisticated scaffolding activities over many iterations, IR4 was eventually in a position to make a larger contribution as a global boundary spanner and formally link members of his firm with foreign partners. He became the project manager in a proposed joint venture between his firm and a foreign investment firm. He was a key leader in setting up the joint venture. His years of scaffolding work had created a readiness for colleagues. He felt that they were ready even though the his firm "had never done anything like this before."

In addition, he "had to educate the foreign firm about the Korean market" so they would be prepared. IR4 eventually found himself building scaffolding not only for internal members to understand foreign practices, but for foreign partners to understand the practices of his firm. The piece of scaffolding that he put in place made a substantial connection between the internal and external organizations. However, this would not have been possible without all of his previous scaffolding efforts. We can see that after the completion of the JV agreement, an entirely new set of scaffolding for different organizational members, in another field of practice, would be needed 
to make the JV successful.

\section{Discussion}

The above examples demonstrate the importance of actively engaging in scaffolding to manage the introduction of novel knowledge practices and relationships. Boundary spanning involves the introduction of ideas and relationships that are beyond current organizational level capacities to recognize and value without the agency of the boundary spanner. However, pushing the limits of what people within an organization are capable of accomplishing requires paying careful attention to scaffolding. A collective bridge is useful for the integration of knowledge practices across boundaries (Zhao and Anand, 2013), but it requires a readiness which takes consistent and incremental effort over long periods of time.

By interviewing senior returnee managers who were involved in boundary spanning activities throughout their tenure with their firms, we have developed a scaffolding model of boundary spanning. This model helps explain how managers work with their organizations to integrate foreign knowledge practices. While many scholars understand and highlight the importance of actively engaging members of the organization who will be affected by the practices that are being transferred across fields of practice (Barner-Rasmussen, et al., 2014, Levina and Vaast, 2005, Mudambi and Swift, 2009, Schotter and Beamish, 2011), our model describes how boundary spanners go about the work of building these competencies. The collective bridge is a result of multiple people having the skills to span boundaries. While, scholars recognize that boundary spanners are unique managers in global organizations (Au and Fukuda, 2002, Schotter and Beamish, 2011, Yagi and Kleinberg, 2011), a scaffolding model explicates how these uniquely talented managers work to create organizational competencies for integrating knowledge across fields of practice. 
The scaffolding model of boundary spanning frames the activities which able and willing managers enact to help colleagues develop the cognitive, relational, and material resources needed to integrate practices across fields. As Kane and Levina (2017) note, this highlights the important role that boundary spanners play in teaching competencies to other managers. It also emphasizes that these resources cannot be imported all at once, but rather must be learned over time. Birkinshaw, et al. (2017) note that the activities of the boundary spanner have different levels of importance at different times. Competencies can only be developed within the Zone of Proximal Development of the people learning them. Thus, capacity is built stepwise. Attempting to skip steps can result in failure. This was seen in IR1's example of attempting to implement an online sales platform based on an American model before developing more fundamental knowledge of practices that underpinned the project. Thus, scaffolding within the Zone of Proximal Development of the organization must be seen as an important component of the work of boundary spanning. It is what enables the collective bridge to work.

\section{Contribution}

Our model makes several contributions to the literature on global boundary spanning. We contribute to the understanding regarding 'how' boundary spanners are more than simply conduits that facilitate the flow of information and relationships between groups. Boundary spanners enable other individuals to integrate new knowledge practices. The boundary spanning literature benefits from examining 'how' boundary spanners go about the task of managing information and relationships across boundaries. This builds on previous work which has extensively examined the characteristics of boundary spanners (Levina and Vaast, 2006, Mudambi and Swift, 2009) and the configuration of boundary spanners (Zhao and Anand, 2013).

By taking a learning perspective, our study looks at the everyday and even mundane work of boundary spanning. Examining the conditions of boundary spanner scaffolding and the 
enacted scaffolding activities provides insight into the process that managers can utilize to help organizational members integrate foreign knowledge practices.

We also introduce the Zone of Proximal Development as a useful way of understanding effective boundary spanning. Global boundary spanning thus involves more than the relationships and knowledge needed to link internal and external agents; it requires a persistent commitment to the processes and to the people who will be involved in the knowledge practices that result from the boundary spanning. A boundary spanner must be committed to working with organizational members within their Zone of Proximal Development to frame knowledge practices in such a way that they can be adopted effectively across fields of practice.

Another contribution is to show that boundary spanning is a dynamic process that occurs incrementally. When viewed from a learning perspective, the integration of knowledge across fields of practice occurs over time and in incremental stages. Boundary spanners create an environment where network members come to understand, accept, and apply knowledge that was previously outside of their ability to recognize and value (Cohen and Levinthal, 1990). They do this by ensuring that the introduction of new knowledge practices remains within the Zone of Proximal Development of workgroup members. By providing scaffolding to network members, individuals can transfer knowledge within a Zone of Proximal Development. After knowledge has been successfully transferred, returnees can provide more scaffolding and transfer new knowledge that would have been more incongruent with the workgroups logics. These activities are an essential dimension of boundary spanning.

\section{$\underline{\text { Future Research }}$}

This study focused exclusively on the work of individual managers who were creating scaffolding to help their organizational members integrate foreign knowledge practices. This was fitting in our context where returnee managers were entering into firms that had little or no 
experience with international markets. However, we would expect that in MNEs with more substantial international experience, many individual boundary spanning managers will create cognitive, relational, and material scaffolds that would be observable at the organizational level.

A follow-up study could look more directly at the scaffolding activities as a predictor of performance of new international ventures - including international joint ventures. At the initial stages of an IJV, organizational members in both of the partner firms may have limited cognitive, relational, and material connections. By being sensitive to members' Zone of Proximal Development, boundary spanning managers could facilitate the development of a collective bridge by enacting scaffolds as they are required. Based on the scaffolding model, we would predict that a substantial amount of variance in the success of international venturing can be explained by long-term, colleague-focused activities of the uniquely qualified boundary spanning managers. The question must not only look at whether the firm employed managers with the abilities to integrate practices over fields, but also if those managers are persistently willing to enact the cognitive, relational, and physical scaffolding while being mindful of the Zone of Proximal Development of colleagues within their organization.

Future research could extend the scaffolding model to include more observable scaffolding activities within the organization. Scaffolding can be operationalized by examining the outcomes of such activities. Examples of operationalized measures could include an increase of relevant cross-field knowledge of local managers (e.g., foreign-market specific knowledge), increase in the number of shared ties facilitated through the focal boundary spanner, and increase in organizational material resources that are available to members to facilitate their engagement in cross-field practice. The Zone of Proximal Development can be operationalized by examining resistance to the efficient and effective flow of practice. If approached incrementally, resistance to practice may be lower than when practices are introduced suddenly and without concern for 
the current capacity of organizational members to integrate them. A scaffolding approach to the management of integrating knowledge and developing relationships across national fields of practice should lead to better performance of international ventures. 


\section{References}

Alexander, E., Bresciani, S., \& Eppler, M. J. (2015). 'Knowledge scaffolding visualizations: A guiding framework'. Knowledge Management and E-Learning, 7, 179-98.

Aljaafreh, A. \& Lantolf, J. P. (1994). 'Negative feedback as regulation and second language learning in the zone of proximal development'. Modern Language Journal, 78, 465-83.

Allen, T. J., Tushman, M. L., \& Denis, M. S. L. (1979). 'Technology transfer as a function of position in the spectrum from research through development to technical services'. Academy of Management Journal, 22, 694-708.

Au, K. Y. \& Fukuda, J. (2002). 'Boundary spanning behaviors of expatriates'. Journal of World Business, 37, 285-96.

Barner-Rasmussen, W., Ehrnrooth, M., Koveshnikov, A., \& Mäkelä, K. (2014). 'Cultural and language skills as resources for boundary spanning within the MNC'. Journal of International Business Studies, 45, 886-905.

Basu, S., Phelps, C. C., \& Kotha, S. (2015). 'Search and integration in external venturing: An inductive examination of corporate venture capital units'. Strategic Entrepreneurship Journal, 10, $129-52$.

Best, K. C. (2011). 'Inductive supervision as a scaffolding mechanism for improving employee performance'. Journal of Leadership and Organizational Studies, 18, 397-407.

Birkinshaw, J., Ambos, T., \& Bouquet, C. (2017). 'Boundary spanning activities of corporate HQ executives: Insights from a longitudinal study'. Journal of Management Studies.

Birkinshaw, J. M., Holm, U., Thilenius, P., \& Arvidsson, N. (2000). 'Consequences of perception gaps in the headquarters-subsidiary relationship'. International Business Review, 9, 321-44.

Björkman, I., Barner-Rasmussen, W., \& Li, L. (2004). 'Managing knowledge transfer in MNCs: The impact of headquarters control mechanisms'. Journal of International Business Studies, 35, 443-55.

Bourdieu, P. (1977). Ouline of a Theory of Practice. Cambridge, UK: Cambridge University Press.

Burgelman, R. A. (2011). 'Bridging history and reductionism: A key role for longitudinal qualitative research'. Journal of International Business Studies, 42, 591-601.

Carlile, P. R. (2002). 'A pragmatic view of knowledge and boundaries: Boundary objects in new product development'. Organization Science, 13, 442-55.

Carlile, P. R. (2004). 'Transferring, translating, and transforming: An integrative framework for managing knowledge across boundaries'. Organization Science, 15, 555-68.

Charmaz, K. (2014). Constructing Grounded Theory 2e. Thousand Oaks, Calif: Sage. 
Cohen, W. M. \& Levinthal, D. A. (1990). 'Absorptive capacity: A new perspective on learning and innovation'. Administrative Science Quarterly, 35, 128-52.

Cole, M. (1985). The zone of proximal development: Where culture and cognition create each other.In Wertsch, James V., (Ed.), Culture, Communication, and Cognition: Vygotskian Perspectives. New York: Cambridge University Press.

Coleman, J. S. (1988). 'Social capital in the creation of human capital'. American Journal of Sociology, 94, S95-S120.

Dai, O. \& Liu, X. (2009). 'Returnee entrepreneurs and firm performance in Chinese hightechnology industries'. International Business Review, 18, 373-86.

Daniels, J. D. \& Cannice, M. V. (2004). Interview studies in international business research.In Marschan-Piekkari, Rebecca \& Catherine Welch, (Eds.), Handbook of Qualitative Research Methods for International Business. Cheltenham, UK: Edward Elgar.

Denzin, N. K. \& Lincoln, Y. S., (Eds.). (2005). Sage Handbook of Qualitative Research. 3rd ed. Thousand Oaks, CA: Sage Publications.

Doz, Y. (2011). 'Qualitative research for international business'. Journal of International Business Studies, 42, 582-90.

Eisenhardt, K. M. \& Graebner, M. E. (2007). 'Theory building from cases: Opportunities and challenges'. Academy of Management Journal, 50, 25-32.

Erlandson, D. A., Harris, E. L., Skipper, B. L., \& Allen, S. D. (1993). Doing Naturalistic Inquiry: A Guide to Methods. Newbury Park, CA: Sage.

Filatotchev, I., Liu, X., Buck, T., \& Wright, M. (2009). 'The export orientation and export performance of high-technology SMEs in emerging markets: The effects of knowledge transfer by returnee entrepreneurs'. Journal of International Business Studies, 40, 1005-21.

Fry, J. N. \& Killing, J. P. (1989). Strategic Analysis and Action. Scarborough, ON: Prentice Hall Canada.

Gibbert, M., Ruigrok, W., \& Wicki, B. (2008). 'What passes as a rigorous case study?'. Strategic Management Journal, 29, 1465-74.

Glaser, B. G. \& Strauss, A. L. (1967). The Discovery of Grounded Theory. Chicago: Aldine. Granovetter, M. S. (1973). 'The strength of weak ties'. American Journal of Sociology, 78, 136080 .

Grewal, R. \& Tansuhaj, P. (2001). 'Building organizational capabilities for managing economic crisis: The role of market orientation and strategic flexibility'. Journal of Marketing, 65, 67-80.

Harzing, A.-W., Pudelko, M., \& Sebastian Reiche, B. (2016). 'The bridging role of expatriates and inpatriates in knowledge transfer in multinational corporations'. Human Resource 
Management, 55, 679-95.

Hendry, C. (1996). 'Understanding and creating whole organizational change through learning theory'. Human Relations, 49, 621-41.

Hsiao, R.-L., Tsai, D.-H., \& Lee, C.-F. (2012). 'Collaborative knowing: The adaptive nature of cross-boundary spanning'. Journal of Management Studies, 49, 463-91.

Huber, G. P. \& Power, D. J. (1985). 'Retrospective reports of strategic-level managers:

Guidelines for increasing their accuracy'. Strategic Management Journal, 6, 171-80.

Jonkers, K. \& Cruz-Castro, L. (2013). 'Research upon return: The effect of international mobility on scientific ties, production and impact'. Research Policy, 42, 1366-77.

Kane, A. A. \& Levina, N. (2017). "“Am I still one of them?”: Bicultural immigrant managers navigating social identity threats when spanning global boundaries'. Journal of Management Studies.

Kinginger, C. (2002). 'Defining the zone of proximal development in US foreign language education'. Applied Linguistics, 23, 240-61.

Kokkonen, J. (2014). 'Stepping into the emptiness: Scaffolding in organizational transition'. Learning Organization, 21, 193-205.

Koole, T. \& Elbers, E. (2014). 'Responsiveness in teacher explanations: A conversation analytical perspective on scaffolding'. Linguistics and Education, 26, 57-69.

Kotter, J. P. \& Cohen, D. S. (2012). The Heart of Change. Boston, MA: Harvard Business School Publishing.

Landry, R., Amara, N., \& Lamari, M. (2002). 'Does social capital determine innovation? To what extent?'. Technological Forecasting and Social Change, 69, 681-701.

Lecusay, R., Rossen, L., \& Cole, M. (2008). 'Cultural-historical activity theory and the zone of proximal development in the study of idioculture design and implementation'. Cognitive Systems Research, 9, 92-103.

Lee, J.-H. \& Roberts, M. J. D. (2015). 'International returnees as outside directors: A catalyst for strategic adaptation under institutional pressure'. International Business Review, 24, 594-604.

Levina, N. \& Vaast, E. (2005). 'The emergence of boundary spanning competence in practice: Implications for implementation and use of information systems'. MIS Quarterly, 29, 335-63.

Levina, N. \& Vaast, E. (2006). 'Turning a community into a market: A practice perspective on information technology use in boundary spanning'. Journal of Management Information Systems, 22, 13-37.

Levina, N. \& Vaast, E. (2008). 'Innovating or doing as told? Status differences and overlapping boundaries in offshore collaboration'. MIS Quarterly, 32, 307-32. 
Locke, K. (2001). Grounded theory in management research. London, UK: Sage.

Lupton, N. \& Beamish, P. (2014). 'Organizational structure and knowledge-practice diffusion in the MNC'. Journal of Knowledge Management, 18, 710-27.

McFadyen, M. A. \& Cannella, A. A. (2004). 'Social capital and knowledge creation: Diminishing returns of the number and strength of exchange relationships'. Academy of Management Journal, 47, 735-46.

McKibbin, W. \& Martin, W. (1999). The East Asian crisis: Investigating causes and policy responses'. Policy research working paper series of the World Bank (No. 2172). Washington, DC: The World Bank.

Miles, M. B. \& Huberman, A. M. (1994). Qualitative Data Analysis: An Expanded Sourcebook. Thousand Oaks, CA: Sage.

Mudambi, R. \& Swift, T. (2009). 'Professional guilds, tension and knowledge management'. Research Policy, 38, 736-45.

Mudambi, R. \& Swift, T. (2011). 'Leveraging knowledge and competencies across space: The next frontier in international business'. Journal of International Management, 17, 186-89.

Orlikowski, W. J. (2002). 'Knowing in practice: Enacting a collective capability in distributed organizing'. Organization Science, 13, 249-73.

Orlikowski, W. J. (2006). 'Material knowing: The scaffolding of human knowledgeability'. European Journal of Information Systems, 15, 460-67.

Orr, R. J. \& Scott, W. R. (2008). 'Institutional exceptions on global projects: A process model'. Journal of International Business Studies, 39, 562-88.

Pratt, M. G. (2008). 'Fitting oval pegs into round holes'. Organizational Research Methods, 11, 481-509.

Pruthi, S. (2014). 'Social ties and venture creation by returnee entrepreneurs'. International Business Review, 32, 1139-52.

Rhee, M. \& Lee, J.-H. (2008). 'The signals outside directors send to foreign investors: Evidence from Korea'. Corporate Governance 16, 41-51.

Rivkin, J. W. (2000). 'Imitation of complex strategies'. Management Science, 46, 824-44.

Sarasvathy, S. D. (2001). 'Causation and effectuation: Toward a theoretical shift from economic inevitability to entrepreneurial contingency'. Academy of Management Review, 26, 243-63.

Schotter, A. \& Beamish, P. W. (2011). 'Performance effects of MNC headquarters-subsidiary conflict and the role of boundary spanners: The case of headquarter initiative rejection'. Journal of International Management, 17, 243-59. 
Schotter, A., Mudambi, R., Doz, Y., \& Gaur, A. (2017). 'Boundary spanning in global organizations'. Journal of Management Studies.

Stigliani, I. \& Ravasi, D. (2012). 'Organizing thoughts and connecting brains: Material practices and the transition from individual to group-level prospective sensemaking'. Academy of Management Journal, 55, 1232-59.

Strauss, A. \& Corbin, J. (1990). Basics of Qualitative Research. Thousand Oaks, London: Sage.

Szulanski, G. (1996). 'Exploring internal stickiness: Impediments to the transfer of best practice within the firm'. Strategic Management Journal, 17, 27-43.

Tsai, W. \& Ghoshal, S. (1998). 'Social capital and value creation: The role of intrafirm networks'. Academy of Management Journal, 41, 464-76.

Tsoukas, H. (2009). 'A Dialogical approach to the creation of new knowledge in organizations'. Organization Science, 20, 941-57.

Vygotsky, L. S. (1978). Mind in Society: The Development of Higher Psychological Processes. Cambridge, US: Harvard University Press.

Warford, M. K. (2011). 'The zone of proximal teacher development'. Teaching and Teacher Education, 27, 252-58.

Wass, R., Harland, T., \& Mercer, A. (2011). 'Scaffolding critical thinking in the zone of proximal development'. Higher Education Research \& Development, 30, 317-28.

Yagi, N. \& Kleinberg, J. (2011). 'Boundary work: An interpretive ethnographic perspective on negotiating and leveraging cross-cultural identity'. Journal of International Business Studies, 42, 629-53.

Yearwood, J. \& Stranieri, A. (2010). 'Group structured reasoning for coalescing group decisions'. Group Decision and Negotiation, 19, 77-105.

Yin, R. K. (2009). Case Study Research: Design and Methods. 4th ed. Thousand Oaks, CA: Sage Publications.

Zhao, Z. J. \& Anand, J. (2013). 'Beyond boundary spanners: The 'collective bridge' as an efficient interunit structure for transferring collective knowledge'. Strategic Management Journal, 34, 1513-30. 


\section{Figure 1: Conditions for Boundary Spanning Scaffolding}

\section{Representative Quotes}

- Senior Vice President, Company A We meet many different foreign companies and subsidiaries from the US, UK, France, Finland, and Japan. So, the common language is English and the common mindset is western practice. I think my involvement has been really helpful in getting some projects on track.

- Senior Marketing Manager, Company H I was exposed to so many business cases throughout the world, but in Korea they were not well known. People are more easily convinced when you can show them an actual business situation that took place.

- Senior Manager Training, Company F At [University], we have a strong alumni association. I am a key member of the association in Korea. Also, I have worked in several companies in the USA.

- Senior Marketing Manager, Company H Having worked abroad and in foreign companies,

I have several old business colleagues who I keep close professional and personal relationship

- Senior Project Manager, Company A I worked in a US firm for 10 years. I helped developed some kinds of $3 D$ and mobile graphic technology. This type of knowledge is very advanced, and not really available in Korea. I knew it would be difficult to introduce them here but important.

- General Manager External Relations, Company M So, , I think that Korean companies could get a lot more value from their human resources if they could create a culture of more open communication. But this takes years to encourage.

- Statistics Officer, Company F There was a VP who really liked my work. I brought a perspective she had never seen. She has an expertise in my field and she understood the knowledge that I brought. This helped me to be promoted quickly which was good for me. - Senior Project Manager, Company A To get promoted up the ranks of the company, I really felt that I had to keep proving that my foreign experience was valuable... This paid off after some time.

- Senior Project Manager, Company A Most of the work at a huge company like this must be done in connection with others. Even though I bring knowledge, I cannot work by myself. I spent time trying to get to know people from other departments and selling them on my ideas. I did this to start my own project with them. I think that is why I was promoted every year.

- Senior Vice President, Company A If I want to introduce something very new, I go and talk with all of the key individuals and spend time to get them on my side. Then, I introduce a new project.

- Senior Marketing Manager, Company F You have to go out and be with people. They are not going to take our ideas on face value. Everyone wants to make money, but they also have other concerns besides making money. If they don't like you, do you think they want you to succeed and become a boss? I am pushing the envelope here. In order to push the envelope, you need lots of friends. I need to build relationships and to get to know people.

- Senior Vice President, Company K I am involved in most major overseas acquisitions or new projects. Few of my colleagues have the background for this so it' is a major role I serve. - Analyst, Company M Nowadays, we have a chance to work with foreign employees and foreign companies. Part of my job is going to meetings to help solve problems or even to just translate.

- Senior Marketing Manager, Company F You have to see how to add value in a way that local guys can't. You have to create opportunities. Korean companies, if you do not ask, they will leave you alone. If you show a bit of assertiveness and create some things, they say hey this guy is trying to work on something - that is good.

- Senior Manager, Company G You should be more proactive because they don't know what you can provide them. You must be a good seller of your foreign ideas.

- Sales Manager, Company $\mathbf{J} I$ try to be there when they need me. Even if it is just language, it is can be really important for my managers. This is how I get noticed.
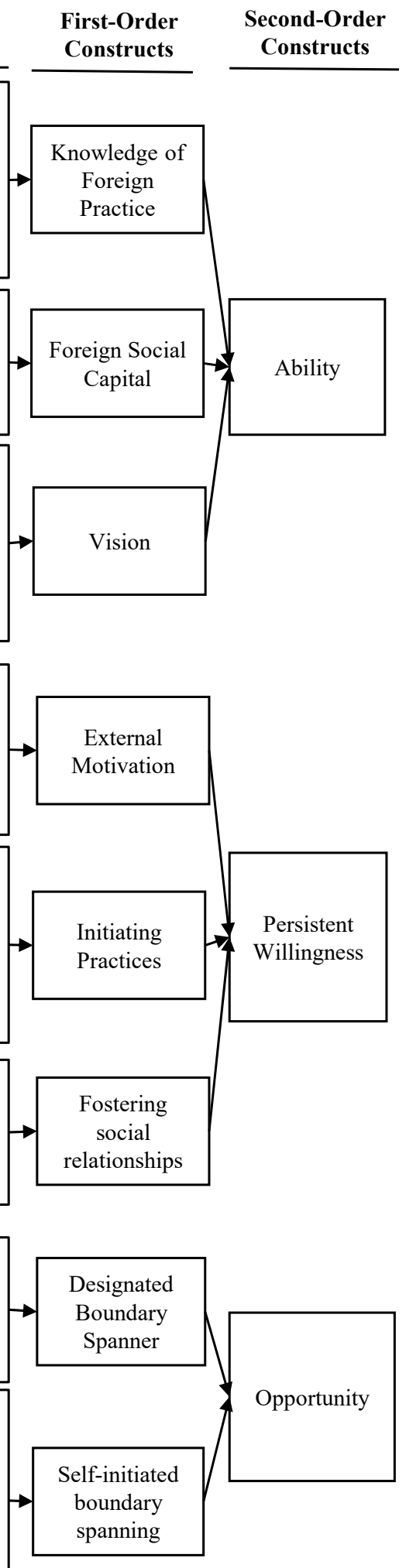


\section{Figure 2a: Scaffolding Activities of Boundary Spanners: Cognitive Scaffolding}

\section{Representative Quotes}

- Senior Marketing Manager, Company L In terms of education, one of the weaknesses of domestic guys is a lack of communication skills in English and global cultural understanding. So in order to improve their capability, we train them. I really push hard on this and even support their studies. We even have a one-year program where we send people all over the world to develop these skills. I just sent a guy to South America.

- Senior Manager, Company G If I don't educate them first, then I cannot present my ideas because they will not understand them. By educating, they can make room for my activity. They can open the door a little wider.

- Senior Vice President, Company K So, when I say problem-solving in [USA firm], everybody knows what that means. It is completely foreign to the folks here. "You're five levels superior to me and you want to have a discussion. I don't understand" They don't have the vocabulary. So, I had to build that from the ground up. It has been challenging...It's more than just the language (Korean or English). The second level is to describe the concept, what does problem-solving mean. The third is the working culture associated with that language. So, explaining intellectually what a problem-solving session is-it is people sitting around a table, on a very equal basis, being able to look at a problem, an issue, and working on it together. Then, we have to do it

- Senior Marketing Manager, Company F So, I talked to our [HR Center] and suggested to them that I would be willing to give one or two hour lectures American style branding. They first needed to understand this approach to branding before they will be willing to expect it.

- Executive Vice President, Company B I end up spending a lot more time with the individual team members than an average [domestic] executive would. I believe that there is a lot that can be gained by working side by side. I can say "here is how the foreign person thinks through things, their logic, and the perspective they use when making decisions." I can bring them through the story line for documents, and the key analysis that we will be expected to do [by foreign partners].

- Senior Division Director, Company N As a person with foreign experience, I see it as a major part of my job to help them develop the thinking skills and understand the process of what they are doing...I always try to get them to think about the vision or strategy.

- Senior Manager, Company G I regularly provided information to the CEO of my company. He sets aside 30 minutes a week to have a direct meeting with me to provide him with information on foreign markets. I provided the various management skills or information.

\section{First-Order \\ Constructs \\ Second-Order \\ Constructs}

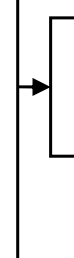

Foreign

language and culture

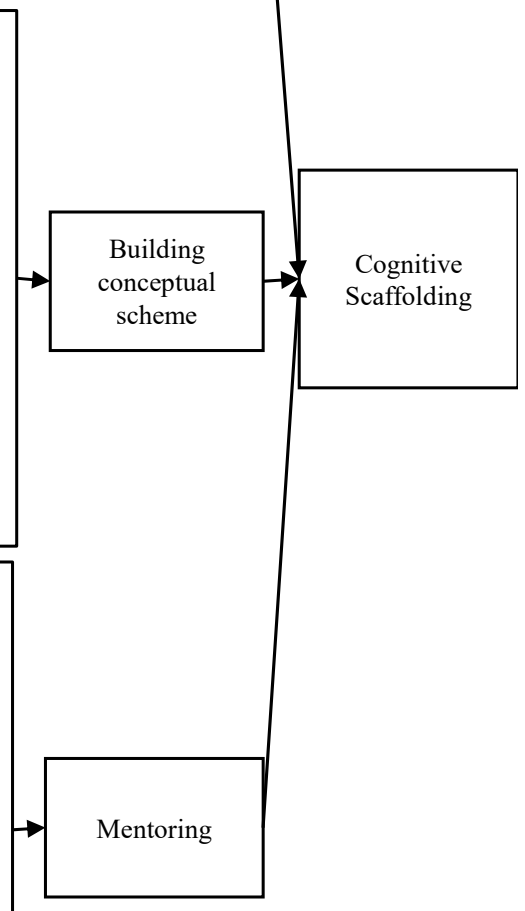




\section{Figure 2b: Scaffolding Activities of Boundary Spanners: Relational Scaffolding}

- Senior Vice President, Company A When we have a large industry level conference outside Korea, we encourage people to go. So they are getting exposure to traveling, and to interaction with foreigners. I make sure that when people go overseas they are not just going to the conference. My office arranges additional meetings in the same trip because we know that there is more value when you take advantage of all the companies that come to that location. In these meetings they see how the industry works outside Korea, and learn the best and new practices of the industry...The goal is for them to establish their own relationships.

- Senior Manager Training, Company F I have a large network. So whenever I need to make a contact in the USA, I use the network. We are starting a benchmarking project. Some executives want to visit global companies in USA. I helped them using my network.

- Senior Marketing Manager, Company $\mathbf{H}$ I invited many of my foreign colleagues to give seminars to executives here at the company. I was trying to open their eyes to new ways of doing business, and encourage partnerships. In fact, when I arrived, my company was only interested in domestic business; they had no contacts in other countries.

- Vice President Global Marketing, Company O People liked the idea of removing some of rigid hierarchical structures, but they didn't know how. So, I invited some HR experts that I know from the U.S. They were able to work with us.

- Senior Executive, Company G I was put in charge because my superiors thought I had demonstrated the knowledge and I had some personal connections. I started negotiating with them because they wanted to enter the Korean market, but they didn't want to set up a wholly owned subsidiary. So, I actually proposed to them that we set up a joint venture company.

- Senior Actuarial Manager, Company $\mathbf{H}$ We are negotiating with foreign suppliers for some expensive programs. My senior managers do not have a background for this so it is hard for them to understand and trust. I am involved as a kind of the middleman.

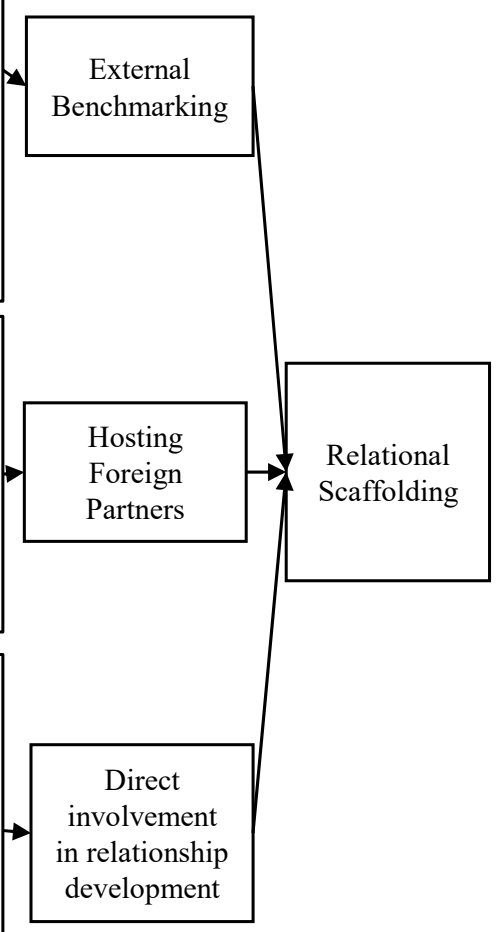




\section{Figure 2c: Scaffolding Activities of Boundary Spanners: Material Scaffolding}

- General Manager, Company J They didn't know about Bloomberg. It seems quite simple now, but no one used it here.... I had large sessions for my colleagues to transfer my knowledge... From the problem solving skills to the technical valuation skills, I had lots of sessions. So after the sessions they started to know... The first session was just the concept...Second session was a case study...Third session we tried to connect things to the real project...Then I had a feedback session.... They don't feel any threat because it is only a lesson. This is how you do it.

- Senior Manager, Company $\mathbf{G}$ At the company we have a very large training center. This is the place to introduce ideas from foreign countries to other managers. It is a lot less stressful for them, so they are more open to listening.

- Sales Manager, Company J We had never done a Non Deal Roadshow for investor relations outside of Korea. But last year we went to Hong Kong and we did the IR for a company which we were going to get listed. Nobody in the company knows how to do this. I had to start from scratch. and use the entire network that I know...I built the system, so even if I am not there, the work can be done...This year they went to India without me... I just had to give them the documents and provide a bit of explanation... It went well.

- Deputy General Manager, Company M Most bond dealers here in Korea do not use those statistics programs. So, I made a program for us to find out the arbitrage opportunity in the bond market. Then I made a document and I sent it to my colleagues and shared the knowledge that way.

- Senior Marketing Manager, Company F We wanted to focus on the corporate message and give some hope and reassurance that the company is there, especially in a time of crisis. But no one ever spent money on a non-product message. So, one thing that I did is to say let's set aside some money and do a series of focus groups. And I presented my results to my VP... The upper guys thought that maybe we had something that was worthwhile and so we presented it without pushing it too hard. When something has never been done or even thought about, you have to show proof of the concept. You have to figure out how to make it make sense to them. It can't seem too foreign.

- Senior Project Manager, Company A So, I spent a long time explaining this technology to my colleagues. Now these technologies are very popular here. I think that this is a real advantage for my company. 
Figure 3: Scaffolding Model of Boundary Spanning

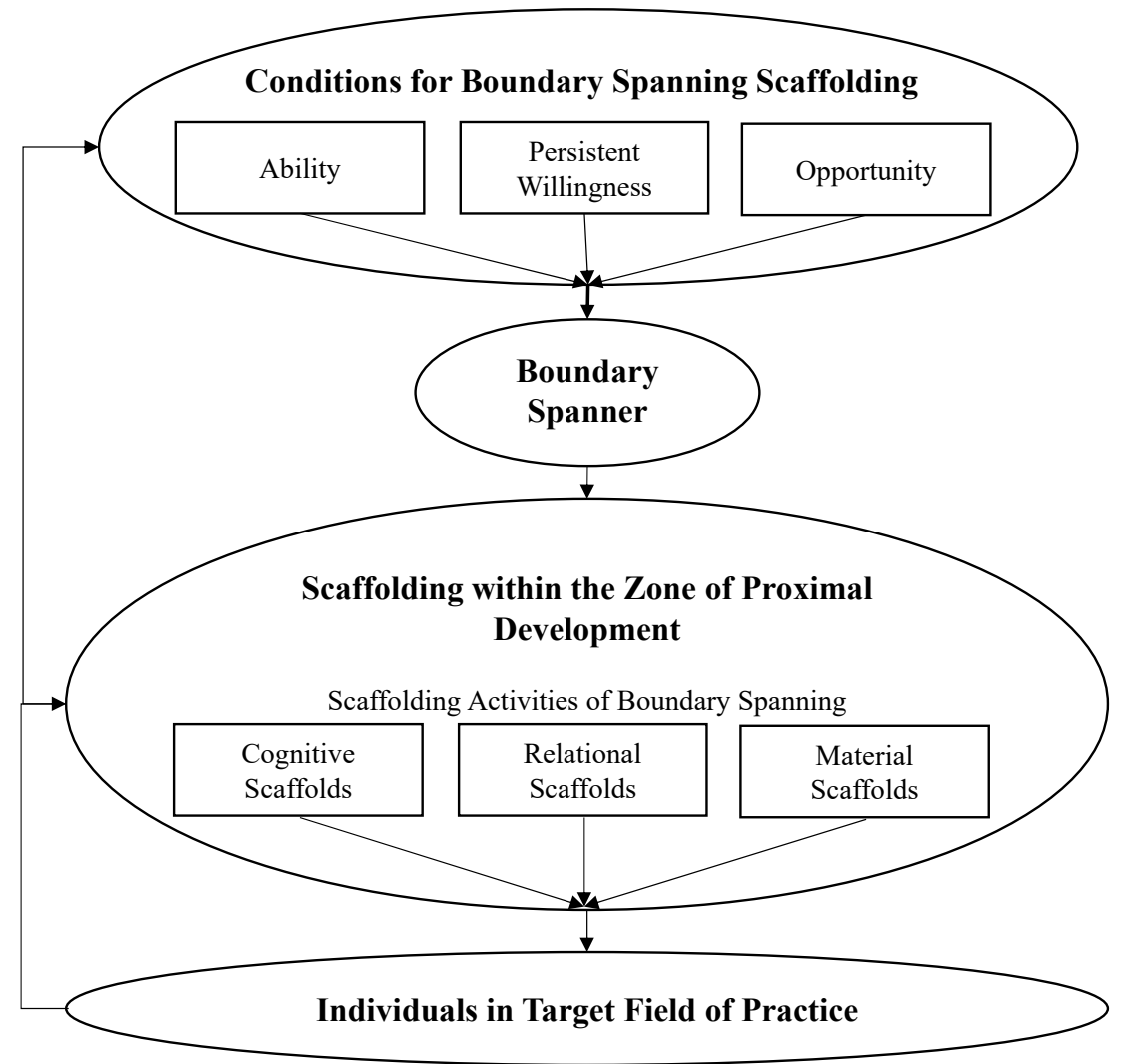


Table 1: Number of returnees participating in the study

\begin{tabular}{ccc}
\hline Phase & $\begin{array}{c}\text { \# of participants new } \\
\text { participants }\end{array}$ & \# of follow up interviews \\
\hline Pilot Phase & 14 & - \\
Main Phase & 23 & 5 \\
Follow-up Phase & 8 & 6 \\
\hline Total & 45 & \\
\hline
\end{tabular}

Table 2: Characteristics of participants $(n=45)$

\begin{tabular}{lll}
\hline Age group & $<30$ & 1 \\
& $31-40$ & 15 \\
& $41-50$ & 17 \\
\hline Gender & $51-60$ & 12 \\
\hline Foreign Country & Male & 39 \\
& Female & 6 \\
\hline & US & 38 \\
& CK & 3 \\
& Germany & 2 \\
& Japan & 1 \\
\hline Type of Advanced Degree & PhD & 1 \\
& Masters & 5 \\
& Business (30); Science \& Engineering (13) Education $(2)$ & 40 \\
\hline Broad Industry & Financial & 26 \\
& Manufacturing & 13 \\
& HQ of diversified firm & 3 \\
& Telecommunications & 2 \\
possible) & Construction & 1 \\
\hline & Senior executives & 11 \\
Prior to Current Position & Korean Company After Returning & 20 \\
& Sonior Managers & 14 \\
\hline Managerial Level & Middle Managers & 18 \\
& Foreign Company While Oversea & 16 \\
& Foreign Company After Returning & 4 \\
& & 14 \\
& & 14 \\
\hline
\end{tabular}


Table 3: Summary of firms visited

\begin{tabular}{cccccc}
\hline Comp & $\begin{array}{c}\text { \# of } \\
\text { Contacts }\end{array}$ & $\begin{array}{c}\text { Description of } \\
\text { Firm }\end{array}$ & $\begin{array}{c}\text { Chaebol } \\
\text { Member }\end{array}$ & Business Scope & Main Business \\
\hline A & 3 & Large Mfg & Yes & MNE & Electronics \\
B & 3 & Large Financial & No & Large Domestic & Bank \& Investment \\
C & 1 & Midsize Mfg & No & Midsize MNE & Medical Equipment \\
D & 4 & Large Mfg & No & MNE & Steel Manufacturing \\
E & 2 & Large Chaebol & Yes & MNE & Corporate HQ \\
F & 8 & Large Financial & Yes & Large Domestic & Insurance \\
G & 5 & Large Financial & No & Large Domestic & Bank \& Investment \\
H & 2 & Large Financial & Yes & Large Domestic & Insurance \\
I & 2 & Large Gen Services & No & Large Domestic & Telecommunications \\
J & 4 & Large Financial & No & Large Domestic & Bank \& Investment \\
K & 1 & Large Chaebol & Yes & MNE & Corporate HQ \\
L & 2 & Large Mfg & Yes & MNE & Electronics \\
M & 4 & Large Financial & No & Large Domestic & Bank \& Investment \\
N & 2 & Large Mfg & Yes & MNE & Steel Manufacturing \\
O & 1 & Midsize Mfg & No & Midsize MNE & Medical Equipment \\
P & 1 & Midsize Mfg & No & Midsize Domestic & Construction \\
\hline
\end{tabular}

Table 4: Summary of Focal Cases

\begin{tabular}{|l|l|}
\hline IR1 & $\begin{array}{l}\text { International Returnee 1 (IR1) was a senior executive in his late 40s with the investment arm of } \\
\text { a large banking firm. He obtained his undergraduate degree and MBA from prestigious } \\
\text { American universities and had worked for large American firms both in the United States and in } \\
\text { Korea prior to joining the Korean bank. As he was raised in Korea until the end of high school, } \\
\text { he was fluent in both Korean and English. }\end{array}$ \\
\hline IR2 & $\begin{array}{l}\text { IR2 was a senior marketing manager in his mid 40s with a large insurance firm. He was born in } \\
\text { Korea but received his formal education in the United States. He completed an MBA with a } \\
\text { specialization in marketing from a prestigious American university. He worked for several } \\
\text { years in the United States for insurance firms before being recruited by his current firm. He } \\
\text { moved back to Korea to join his firm. While English was his preferred language, he was fluent } \\
\text { in Korean. }\end{array}$ \\
\hline IR3 & $\begin{array}{l}\text { IR3 was a senior manager in his late 40s at a large bank. He specialized in external relations. } \\
\text { He had an MBA from a prestigious American university. He completed all other education in } \\
\text { Korea. He worked for large American firms both in the United States and in Korea before } \\
\text { joining his current firm. Korean was his preferred language and his English was fluent. }\end{array}$ \\
\hline IR4 & $\begin{array}{l}\text { IR4 was a senior executive in his late 50s with a large investment firm. He had an MBA from a } \\
\text { prestigious American university. He completed all other education in Korea. He worked for a } \\
\text { U.S. financial firm for a short period in Korea before joining his current firm. While his foreign } \\
\text { experience was arguably less than the other three selected executives, he returned to Korea in } \\
\text { the mid-1990s (much earlier than the others), and thus his foreign experience was quite rare and } \\
\text { became valued by his firm. He was fluent in English. }\end{array}$ \\
\hline
\end{tabular}

